\title{
Moira Pérez
}

Universidad de Buenos Aires, Buenos Aires, AR

Universidad Nacional de Lomas de Zamora

\section{"The Sex-Gender-Revolution Series"}

\begin{abstract}
Resumos: When carrying out political projects, the use of homosexual/heterosexual or trans*/ cis distinctions as exclusive categories of analysis may limit our understanding of the complexity of belongings in which each subject is positioned. In many cases, including some queer approaches, this strategy provides for a simplification which attributes a radical or subversive nature to the first term of the pair and a normal or even repressive one to the second. The former case results in what is here called a "homo-trans*-revolution series"; the latter, in a "hetero-cisrepression series". In both instances, a passage from generalization to reduction to invisibilization obstructs any understanding either of the conservative positions existent in the realm of the homo/ trans*, or of the subversive and radical ones in the sphere of the hetero/cis. Exposing both of them will allow us to understand that a dissident, fertile collective political project cannot be based solely on sexuality or gender: it must build intersectional bridges based on political approaches and objectives, without falling into generalizations, and maintaining the flexibility we seek in queer approaches.
\end{abstract}

Keywords: gender identity, sexual orientation, politics, dissidence, normalization.

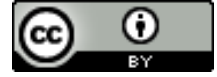

Esta obra está sob licença Creative Commons.

\footnotetext{
1 Judith BUTLER, 1999, p. 30.

${ }^{2}$ BUTLER, 1999, p. 32.
}

Theoretical reflection on sexual and gender diversities, and in particular one of its most recent developments, Queer Theory, has come a long way in its task of detecting, denouncing and dismantling key aspects of the regulations that affect bodies, sexualities and genders. The ways in which each of these categories relates to the other, and the attributes that are culturally assigned to them as "essential", have been some of the main targets of critique from these areas. Within Queer Theory, even as early as in Gender Trouble (1990), usually regarded as one of its founding works, Judith Butler sought to expose the mechanisms whereby a "causal relation" and a "metaphysical unity"' is established among sex, gender and desire, thereby producing a passage along "sequential or causal models of intelligibility" 2 and pushing all alternative configurations to the realm of the unintelligible. On some occasions, these perspectives have also offered tools for political activism, specially the one related to sexual and gender difference, and its struggle for more livable lives. In this 
${ }^{3}$ Néstor PERLONGHER 2008a, $p$ 32. This an all translations from Spanish are mine. respect, the contribution of Queer Theory, particularly in relation to activist struggles, cannot be underestimated.

Nevertheless, it is vital to keep a critical alert vis-à-vis the generalizations we tend to use, perhaps paradoxically, when thinking about diversity. The use of so-called "sexual orientation" and "gender identity" as the only categories of analysis can limit and be detrimental to our understanding of the complexity of identity formations within which each subject is positioned. In particular, when these two categories are used to classify subjects along the homosexual/ heterosexual or trans*/cis axis, it is frequent to find that other belongings are neglected, such as class, geopolitics or religion. This can, in its turn, lead to a simplification that attributes a dissident, radical or subversive quality to the former term of each pair, and a normal or normalizing nature to the second one. Argentine author Néstor Perlongher has referred to this phenomenon in his article "El sexo de las locas" ("The sex of sissies", 1984), where he suggests an explanation of its origins:

When normality is questioned, we should also question the pretense to classify subjects according to who they sleep with. But what mixes things up is that normality bears the flag of conjugal, monogamous heterosexuality. This opens the way for a temptation: claiming a 'revolutionary' homosexuality against a 'conservative' heterosexuality. Some facts, however, sabotage these simplifications. ${ }^{3}$

When exposing "normalities" and establishing alliances with "dissidents", we often run the risk of identifying "the norm" (and normality) with heterosexuality -and, we could add, although this brings its own complexities, cissexuality- and subversion, queerness and radical potential with homosexuality and trans* identities. In this way, new "sequential models" take shape, where instead of establishing a sexgender-desire series, we find one linking sex, gender and revolution, or more specifically, a "homo-trans*-revolution" positively invested interlocking, and a "hetero-cis-repression" negative one.

This paper intends to bring an analysis of the mechanisms that ground these types of approaches and the underlying assumptions that enable them, as well as some theoretical and practical consequences they can entail. The work will be structured around those two series, which are to function as axis of my analysis. Firstly, I will consider the functioning of the homo-trans*-revolution succession, and the ways in which it veils or denies what, following Susan Stryker and Lisa Duggan, I will call "homonormativity": the problems that can be found within the LGBT collective, including cissexism, 
4 For some examples in the Argentine context, see "Hagamos la revolución, iconviértete en lesbiana!" ("Let's make revolution, become a lesbian!") in https:// lamula.pe/2013/10/13/hagamosla-revolucion-conviertete-enlesbiana/feministas/, or Virginie Despente's idea that "becoming a lesbian would be a good start [for revolution]", in http://elpais.com/ diario/2007/01/13/babelia/ 1168648752 850215.html.

${ }^{5}$ DUGGAN, Lisa, 2002, 179. It is important to note that, though there is a certain consensus in attributing to Duggan the notion of "homonormativity", the same term had already been used within trans* activism to designate "the ways that homosexuality, as a sexual orientation category based on constructions of gender it shared with the dominant culture, sometimes had more in common with the straight world than it did with us [trans* people]" (STRYKER Susan, 2008, 146). normalization and political conservatism. On the other hand, I will analyze the hetero-cis-repression sequence, which attributes reactionary traits to hetero/cis people, while precluding any understanding of "heteroqueerness", or the ways in which heterosexuality, cissexuality and cisgender can be part of radical and queer politics. Each of these tendencies can be read through exemplary cases -in Perlongher's terms, "facts" that "sabotage these simplifications". On this occasion, I will bring to the fore one example related to the homo-trans*revolution sequence, and its flipside in the concealment of "homonormativity", and another that expresses the hetero-cisrepression series and occludes the potential of heteroqueerness. Through this twofold inquiry, I expect to show how the tendency to think political alliances solely in terms of sexgender diversity, without considering other differences, presents a number of difficulties in terms both of what it enables and what it impedes or leaves out of sight. This highlights the need to reclaim the efforts devoted from the beginnings of Queer Theory (and before) to questioning the links of that sexgender-diversity chain, and apply them to fight the linkages reproduced within LGBT activism, theory and practices when we equal homo, trans* and queer with "radical" and hetero or cis with "normative"4.

\section{The Homo-Trans*-Revolution Series and the Role of "Homonormativity"}

In "The New Homonormativity: The Sexual Politics of Neoliberalism" (2002), Lisa Duggan adopts the term "homonormativity" to describe "a politics that does not contest dominant heteronormative assumptions and institutions but upholds and sustains them while promising the possibility of a demobilized gay constituency and a privatized, depoliticized gay culture anchored in domesticity and consumption". ${ }^{5}$ Although Duggan acknowledges that the "normativity" in "homo" will never attain an equal status to the "heteronormativity" described by Michael Warner (from whom she takes inspiration in these reflections), she still denounces a strong assault by political and economical conservatism in the last few decades, particularly in the hands of white, republican gay men in the United States.

In this section, I would like to look into the ways in which this kind of "homonormativities" are rendered invisible (or even denied) when the homo-trans*-revolution link is applied. In order to go into the details of this turn, I will work with a debate that took place within Argentine LGBT activism in 2012 , triggered by the social media circulation of an image that caused considerable stir. Florencia de la V, a TV host, actress and public transsexual figure, was featured in the

Estudos Feministas, Florianópolis, 25(2): 435-449, maio-agosto/2017 437 
${ }^{\circ}$ Caras Argentina magazine, August 28th 2012

${ }^{7}$ Lohana BERKINS, 2012.

${ }^{8}$ PERLONGHER, 2008, p. 88; BUTLER, 2004, p. 115. cover of the weekly magazine Caras, where she talked about her babies' Catholic baptism in a piece entitled "I want my children to grow in this faith". ${ }^{\circ}$

This image and the host's statements severed the community and met, from one side, accusations of betrayal to the LGBT cause and questionings of her personal -and political, of course- choices. How could a transsexual person choose to join an institution that had historically oppressed and discriminated against sexual and gender minorities? What explanation could this woman provide of her behavior, so alien -and even opposed- to the discourse of LGBT activism? Shouldn't she make use of her visibility as a public figure to draw attention to the problems of the collective? These and other reactions emerged rapidly, along with direct accusations of plain silliness and banality. From the other side of the debate a different position emerged, less corrosive towards the star, but blunt towards her critics (mainly cis gays and lesbians): it questioned the constant need to inspect and judge each action of a trans* person, even ones that when done by a cis person did not raise any comments. Why did she have the obligation to adopt a certain political stance? Why did she have to carry the flag of trans* rights - or even the rights of cis gay, lesbian and bisexual people? What about all those cis people -both homo and hetero- that are not questioned for taking a similar path in life? In a sense, it was a call for finally allowing people like Florencia de la $\mathrm{V}$ to build their own life projects, without holding them accountable for all their actions, and without having to prove an activism that they do not have nor wish to have. ${ }^{7}$

This is a long-standing discussion in the LGBT and/or queer arena. Even in historical terms, activists and theorists have often wondered "whatever happened to us", where did the LGBT collective take a wrong turn, from its supposedly revolutionary past in which it seems to have been a strong arm of the civil rights and political movement, to our days, when our biggest collective dream is to baptize our children in a downtown church. For example, there are those who have noted 8 that this "normalization" may be largely explained by the so-called AIDS crisis, when many homosexual people tended to fight the stigma of promiscuity by proving that a non-heterosexual person could also be "normal", a "serious citizen" that aspires to a monogamous, nuclear family with a house and a dog. In Homografias (1999), Llamas and Vidarte understand this phenomenon as a matter of adaptation, a kind of "pink Darwinism". They refer to

an ecological strategy of natural selection that is only willing to grant rights to the individuals that best adapt to their environment: and this environment is homophobia. Adapt to our homophobia, get rid of the acquired and/ 
${ }^{9}$ Ricardo LLAMAS and Francisco Javier VIDARTE, 1999, p. 13.

${ }^{10}$ LLAMAS and VIDARTE, 1999, $\mathrm{p}$ 13.

$"$ LLAMAS and VIDARTE, 1999, $\mathrm{p}$. 14. or inherited characteristics that are not convenient for you, and we shall grant you the corresponding rights. ${ }^{9}$

Thus, whoever does not adapt to the environment (the authors refer specifically to "feathery homosexuals, the flashy, the loud, the promiscuous, those who kiss in public"10) are seen as a burden, an obstacle to social integration. In a notably perverse turn, the same political correctness supposedly established for the benefit of marginalized groups, is now used to repress those same groups in their less "adapted" aspects."

This diagnosis of the contemporary LGBT collective as a scene of depolitization (unfortunately so, according to criticisms against Florencia de la V) can also be rooted in an analysis of the relations between the collective and the global market. It should be said that a non-hegemonic sexuality or gender does not immunize us against contemporary phenomena such as capitalist consumer markets. In our days, many industries have found a niche within certain sectors of the gay and lesbian collective (mainly the former), and nothing suggests that it will let them go without a fight. The "pink dollar" phenomenon shows the market's interest in capturing some segments of the LGBT community (although it is actually a small portion of it) within the upper spheres of global consumer circuits. This tendency, along with "pink washing" and many other "pinks", should lead us to consider all that can be done with "pink" -including tendencies which we may wish to endorse, and others we will most certainly not. The question that still stands is: what makes us think that one experience - in this case, that of not being heterocissexual - sets off or determines the others -such as a certain political stance, or a way of living our own socio-economical position? In our contemporary global context, it might not be at all obvious that we are more inhabitants of our sex-gender classification than of a consumer market that calls upon us directly and constantly.

There may very well be some truth to all this: that the AIDS crisis, topped with a decade in the Global North that was conservative in many respects, pushed part of the collective to seek a new, fresh image, and that in the past few decades the struggle for human rights (not only in relation to sexual orientation and gender identity rights) has taken a more hygienist stance than what many of us would like to acknowledge. It is also true that the market calls upon us, puts pressure on us - on some occasions, we seem even more called upon by the market than by sex. Nevertheless, if we wonder why that homo-trans*-revolution series does not apply to every case (or at least not as some would like it to), there is a key issue that is often overlooked: that we just are different people, and

Estudos Feministas, Florianópolis, 25(2): 435-449, maio-agosto/2017 439 
12 In this respect, see the criticism in Viviane NAMASTE, 2005, p. 19 This is not to say, of course, that such stances are not to be found in current Queer Theory as well.
${ }^{13}$ NAMASTE 2005, p. 4

${ }^{14}$ Ibid., p. 6 we want different things. And the fact that we share the same "sexual orientation" or "gender identity" box does not make that any less so.

Maybe the problem lies in the question itself, in that "Whatever happened to us? (how did we become normal?)". We might want to consider whether there is only one ("not normal", radical, politicized) possible way of being homosexual, bisexual or trans*. The seed of this doubt clashes with those discourses that identify difference regarding normative genders and sexualities with other types of difference, or even with an active dissidence or an antihegemonic political stance. The first steps of Queer Theory, mainly those around Butler's production, were marked by claims that seemed to regard, for example, drag practices as inherently subversive, while transsexual people who did not uphold the discourse of sexual or gender disruption were explicitly rejected. ${ }^{12}$ Over twenty years later, we should be able to learn from those mistakes, inquire in other directions and acknowledge that a certain gender or sexual identification does not necessarily bring about political dissidence or a quest for alternative walks of life.

The practice of aggregating each of these collectives under a same banner, with their profoundly different needs, agendas and opportunities, is in itself problematic, and involves dangerous hierarchies. Canadian sociologist Viviane Namaste has shown that in the case of trans* people, and particularly transsexuals (as is the case with Florencia de la V), this is an extremely common device in Queer Theory and activism, based on a number of questionable assumptions. On the one hand, the impulse to bring these subjects together under the "LGBT" umbrella usually stems from cis lesbian, gay and/or feminist collectives, and serves their voices and needs. The voice of trans* people, on the contrary, is rarely heard, except in some specific cases in which the individual speaks not as trans*, but as gay, lesbian or bisexual. This implies, according to the author, that "transsexuals who do not make sense of their lives according to lesbian/gay discourse" cannot express themselves in their own terms, and thus "have no voice" in activism, theory or institutions. ${ }^{13}$ On the other hand, as was mentioned before in relation to Butler, this kind of discourse assumes that trans* people "will see their own bodies, identities and lives as part of a broader process of social change, of disrupting the sex/gender binary", while in fact many of them see themselves as "women" or "men", not as "gender radicals" or "gender revolutionaries". ${ }^{14}$ At the root of this logics lies the consideration (usually presented by those same cis gay, lesbian and/or feminist scholars) of the sex-gender binary system as an oppressive institution that must be fought against, and of transgender people as those who have successfully 
${ }^{15}$ Ibid., p. 8.

${ }^{16} \mathrm{lbid} ., \mathrm{p} .9$.

${ }^{17}$ I am aware of the turn from a "homo-trans*" realm in the previous section to a "hetero" (not "heterocis") realm in this one, as I will refer to "heteroqueerness" and not "hetero-cis queerness". This is because the allegations I will be analyzing in what follows are almost exclusively directed against cis heterosexuals, as they attribute all negative features to heterosexuality, without mentioning cissexuality or cisgender. This might not be by mere chance, as such evaluations are usually presented by cis homosexuals, as we will see in the following note. The practices of displacement from homo (or queer) to trans*, and their tricky rhetoric, call for a much deeper analysis than what can be offered here; for thorough analysis of , see NAMASTE 2005 and Blas RADI, 2015.

${ }^{18}$ This is the case, for example, in the campaign organized after the death of "la Pepa" Gaitán, who was murdered by their girlfirend's father in the Argentine city of Córdoba in 2011 . This is a particularly complex case, because after this event their sex and gender has alternatively been described as cis female -in which case their murder is under stood as a hate crime against a lesbian - or as trans male, which would turn the crime (and lesbian feminist approaches to it as the murder of a woman) as a case of transphobia. Some examples of this sequencing exercise can be found in: "Heterosexuality kills! Long live La Pepa!!!", published in the website of Malas Como Las Arañas, a collective from La Plata, Argentina, formed by cis lesbian feminists (http://malascomolasa.blogspot.com. ar/201 1/08/la-heterosexualidadmata-viva-la-pepa.html); "La heterosexualidad nos mata" ("Heterosexuality kills us": http:// djovenes.org/archivo/?p=9362), or "A propósito del 25 de noviembre" ("Regarding November 25th, International Day against Violence towards Women: http://desacatofe minista.com/2012/11/27/aproposito-del-25-de-noviembre). challenged such a system. Again, a large portion of trans* people, mainly transsexuals, are foreclosed by an agenda that is alien to them, and to their everyday needs and desires. This kind of approach is grounded, according to Namaste, in a subtle but deeply problematic shift, that starts by considering that trans* people are at the forefront of the struggle against the sex-gender system, and goes on to require that trait as proof of "political usefulness" of trans* subjectivity. What is the problem with this? In her words: "I think that academics and activists set a very dangerous precedent if we maintain that people's identities are acceptable only if and when they can prove that they are politically useful. Who gets to decide what constitutes 'politically useful' anyway?". ${ }^{15}$ On the other hand, and in relation to what we saw before with Berkins, this continues to reinforce a dynamic in which trans* people must offer proof of their worth, instead of just being valued or respected for what they are: "if we accept transsexuality in and of itself, then we don't need to make it conditional on a particular political agenda." 16 The fact that these calls for uprising originate in subjects that are not part of the transsexual collective, and whose agenda does not address the needs of the latter, is particularly alarming, and adds further problems to the already questionable homo-trans*-revolution series.

\section{The Hetero-Cis-Repression Series and the Role of "Heteroqueerness"}

As a flip side of this attribution (and obligation) of political dissidence to sexual and gender difference, another discourse takes shape to link hetero-cis-repression. This discourse attributes a lack of political involvement to heterosexual individuals and collectives, thereby masking their "heteroqueer" expressions; in other cases, it can even define them as straightforwardly conservative, repressive or destructive. ${ }^{17} \mathrm{~A}$ good example can be found in a slogan widely circulated in Argentina in the last few years, where it screams across walls and banners: "Heterosexuality kills". ${ }^{18}$ As a motto, this is often used by certain groups within gay-lesbian activism and lesbian feminism, for example when demonstrating against homophobic and transphobic crimes, or against murders related to violence from (cis) men to (cis) women, described under the entity of femicide. This motto, and its extremely vehement repetition, condense paradigmatically a variety of theoretical and political contents upon which it is necessary - and urgent - to reflect. Just like in the previous case there was a tendency to identify non-normative genders and sexualities with a subversive political stance, in this case the opposite operation takes place, identifying heterosexuality 
with the defense of sexual and gender norms, bodily hegemonies, and the repressive - even deadly - consequences that they have on people. The root and cause of hate crimes or femicides is not attributed to cisgender, even when they are perpetrated on trans* people. Neither is there a blame placed on transphobia, heterossexism, or compulsive heterosexuality, but rather a blaming of heterosexuality itself - that is, the possibility and wish to maintain sexual or emotional desires and relations with people of an "opposite" sex (which, of course, already implies that these "opposites" are two and separate, an assumption contained in the very concepts of heterosexuality and homosexuality, where it is seldom questioned).

It is undeniable that in our culture, heterosexuality and cisgender, if we think them in themselves and isolated from any other identification, occupy hegemonic sites. In many realms, non-heterosexuals encounter larger obstacles for their personal or professional development, and even for their survival, than someone identical in every trait, except for their sexuality. In the case of trans* people the gap widens, and can be found even within gay and lesbian activism; in a shocking amount of cases these forms of exclusion can lead to death or to an appallingly low life expectancy. Far from settling the issue, however, these assertions open many more questions. Because if the "problem" of, say, a homosexual person is not their homosexuality (although "rehabilitation" clinics might disagree), but the way in which our society relates to non-normative sexualities, then how can we say that the problem of heterosexuals is their heterosexuality? (And how could it be at the roots of the homicide of a trans* person?). On the contrary, these perspectives invite us to consider the other conditions that affect each subject, given that someone can be privileged in relation to sexuality and gender, but not in relation to other aspects. On the other hand, one could also look into what that person (heterosexual, cissexual, heterocissexual) does with that privilege and how they use it, as privilege can also be turned into a contribution for a certain social struggle. In those cases, the series that begins with hetero-cis could be completed with dissidence, insurgence or solidarity.

At the risk of stating the obvious, it might be useful to add that the heterosexuality of a heterosexual person is neither a sufficient nor a necessary reason for them to commit a crime against a non heterosexual individual, and that if we followed that line of thought then hate crime rates would be much higher than they already are. If what "kills" is not heterosexuality, then it might be, among other things, the harshness of heterosexist norms and its prejudices.

But then, one might want to ask: what is "killed" by that prejudice according to which "heterosexuality kills"? Something it certainly "kills", or avoids, are all the other 
experiences that constitute identity, all the different ways of being heterosexual -some that feed heterosexist violence, and others that fight it. This neglect reinforces the idea of a necessary connection between gender and politics or gender and ethics, resulting on the one hand in the heterocis-repression sequence, and on the other in the veiling of "heteroqueerness", as all that falls under the category of "heterosexuality" would seem to be subsumed under the attribution of violence and repression.

One of the main contributions of Queer Theory is its ability to think of identity not as something static, but as a positioning within a network of multiple experiences, traits and materialities. This positioning is temporal and contingent, not only from one individual to another, but in each of us too, as identities are, after all, relational. Still, when we reproduce tendencies such as the interlocking of heterosexuality with homophobic or transphobic violence, we are in fact assuming that a certain sexual or gender identification leads to a political stance (in this case, unlike the previous one, a reproachable one). This seems to come dangerously close to that essentialism -that Queer Theory and activism have fought so fiercely - according to which a certain sex, gender or desire possesses certain inherent traits, be them related or not to the subject's sex or gender. It is my contention that, far from this, we must understand that analyzing a subject's attitudes and motivations entails much more than defining the way in which they live their sexuality, their sex or their gender: it means, above all, establishing an intersectional approach that can give an account of a complex network of belongings, identifications and relations that act on -although we can hardly say that they "explain"- a human being and their actions.

This reveals how the sex-gender-desire sequence is established for the subjects assigned to the negative side of the equation: assuming a certain political stance on the basis of a heterosexual identity or practice, may entail transforming subjects into tedious examples of normality, at the least, or in violent heterocissexist fundamentalists, at worst. But this is not only about what is smuggled into a description (conservativeness, repression, violence), but also about what is obscured. Because even if we limited our analysis to the sex-gender system, leaving out any other identification that could affect an individual, what about all those small battles that people identified as heterosexual fight against sexual and gender norms on a daily basis? Is there an only way of being heterosexual? Even before the advent of Queer Theory, theorists such as Gayle Rubin had already considered some of those variations, as in her "magic circle" of socially accepted versus

${ }^{19}$ Gayle RUBIN, 1999, p. 153. blacklisted sexualities. ${ }^{19}$ These go well beyond sexual orientation and gender identity: the age of people involved in 
a relationship, the location of practices, whether or not there is money involved, whether there is a BDSM (bondage, domination, sadism, masochism, etc.) agreement, among many others. All of this leads us to wonder: shouldn't "hetero" be nothing but the description of a number of sexual and affective desires -and not even all of them-? And, returning to what was said above, shouldn't "trans" be, as Namaste warned us, nothing but the description of a certain way of relating to the sex and/or gender assigned at birth?

\section{The Generalization-Reduction- Invisibilization Series}

Both when hetero is identified with the normative (even repressive) as when homo and trans* are aligned with the subversive, the root of the problem seems to be in the reduction of identity to a single axis - in this case, contending that the terms of sexual orientation or gender identity are determining factors for our ways of being. This is problematic for many reasons. Firstly, it seems to reproduce what LGBT and queer activism and theory have tirelessly pointed out: the tendency to attribute a certain trait to a collective (rooted in an actual practice or not) solely based on their particular sex or gender. If we analyze this from a logical perspective we can wonder: what is the difference between saying that all gay people are promiscuous (meant as an insult by the person who says it) and saying that all gays are revolutionaries? Between saying that being trans* is being sick, and saying that being trans* equals to being at the vanguard of social change?

On the other hand, this tendency seems to entail a certain pressure on subjects to pick one of these identifications, from which the rest of them would unfold. We are thus forced to choose: if someone presents herself as a woman, then we could automatically deduce that she fights for women's sexual and reproductive rights. But if she presents herself as a white person of European descent, then her environment will receive her as an irrecoverable colonialist. And if she identifies as pansexual, one can hardly know what will be assumed because the issue of pansexuality is far from being settled, although it exceeds by far the scope of this work. Which identification should we choose? Why choose one? Why choose? We are probably these and many other things - but are we so essentially, necessarily, because we are a woman, or white, or pansexual? Or are we rather the somewhat random combination of all those impulses, in a balance that shifts every day?

These linking practices begin with a generalization, then move on to restrict the horizon of possibilities for the subjects and collectives to which they refer, and finally result in the 
${ }^{20}$ QUEER NATION, 1990. invisibilization of what lies outside of these possibilities - above all, the hegemonic aspects of straightness, and the queer possibilities of heterosexuality. What were the mechanisms involved in the constitution of this series, and which are still in force guaranteeing its reproduction? In a previous section I mentioned that some activists and scholars are wondering "whatever happened to us", considering that the problem lies in the depolitization of a movement that in its origins seems to have been actively counterhegemonic. Such critiques are mostly aimed at the impulse to prove one's own "normality" against conservative attacks; ironically, we now find a conservative insistence on upholding restrictive generalizations both for those who are left outside the homo/trans* circle and for those who are allowed into it. It remains to be understood, then, what are the concrete, political results of these sequences today.

Series such as these may have served their purpose as a cohesive strategy, mainly in the beginning of the political organization of gay-lesbian collectives. This allowed them to frame "heterosexuals" as a unified and antagonistic whole, portraying them as "enemies", and configuring each "side" as a compact and discreet box (Queer Nation manifesto "Queers read this" ${ }^{20}$ is a good example in this regard). One might suggest that they were effective in joining ranks when it was time to advocate certain political claims - although perhaps they were not. This discussion notwithstanding, and leaving aside whatever might have been the case in the past, it is fundamental to remain suspicious of what the purpose is today of establishing alliances for political ends on the sole basis of sexual or gender identifications. Or has our conceptual apparatus, so successful in challenging the necessary and essential nature of the link between sex and gender, not succeeded in contesting the one between sex and politics or gender and politics? If it is a matter of political alliances, shouldn't we establish them on the basis of political stances, rather than over a particular sexuality or gender? This change might allow us to open up the spectrum of possibilities for all those with whom we share political affinities (including "heterosexual" people who do not "kill"), affinities that may even be greater than those that bind us to those who partake in our sex or gender identification.

This work involves maintaining a critical view on our own essentialist shifts and the linkages they nourish, be it when forming alliances (with an apparent homo-trans* "dissidence", which has little to do with that world managed by the "pink dollar") or rivalries (embodied here in a heterosexuality that "kills" - where in addition to generalizing, the role of cissexism and transphobia is omitted), and even when establishing these two categories as static and completely separate. This exercise

Estudos Feministas, Florianópolis, 25(2): 435-449, maio-agosto/2017 445 
${ }^{21}$ PERLONGHER, 2008b, p. 88.

can help us work towards a greater coherence between our political journey, our goals for the future, and the theoretical approaches adopted to interpret the networks of identifications that surrounds us.

\section{Queer Dissidence and/or Beyond}

When Perlongher referred to "the disappearance of homosexuality" he did not understand it as the extinction of a variety of sexual practices, nor as the return to the underground practice to which they were restricted in many societies, and still are in considerable portions of the globe. Rather, he referred to the almost imperceptible disappearance of the "noise" that these practices made due to their radical character. Thus, what Duggan identified as "homonormativity", i.e. the normalization and depoliticization of homosexuality (the realm Perlongher is interested in), would fulfill what Foucault (2002) anticipated: the sexuality device, emptied of its meaning, just fades quietly. Homosexuality becomes something normal, irrelevant, apolitical: "By making it completely visible, the offensive of normalization has succeeded in removing all mystery from homosexuality, banalizing it completely". ${ }^{21}$ It is important to note that in this respect both Perlongher and Foucault would seem to assume that at some point in time homosexuality was marked by this radical character, due to its deviation from behaviors expected by the society in which it was and is inserted. The visibility of homosexual practices would have stripped them of their subversive content, integrating them into a society that would thus be saved from a potentially dangerous source of infection. Although I do not intend to enter the debate on the history of these processes, it is interesting to see how the authors' contention reminds us that identitarian positionings can function collectively but apolitically, and that homosexuality in particular today does not entail in and of itself a locus of political radicalism, or a position that "makes noise" or is interested in doing so. The question that remains to be solved at this point, then, is how we can "make noise again".

Any answer should take into account, first and foremost, the fact that not every homosexual and/or trans* person has the desire, impulse, need, or obligation to "make noise" or, in other words, be politically active and radical. The debate around Florencia de la $\mathrm{V}$ (who, as we have seen, was strongly criticized for being a trans* woman with a lifestyle attuned to what is expected of a public entertainment star) showed how, on the one hand, trans* people are assumed or expected to experience their gender identity as a political stance or a form of dissent, and on the other hand - and as a consequence of that - are judged negatively when they do

446 Estudos Feministas, Florianópolis, 25(2): 435-449, maio-agosto/2017 
${ }^{22}$ NAMASTE, 2005, p. 10.

${ }^{23}$ Alfonso CeBALlos MUÑOZ, 2007, p. 167. not live up to those expectations (or at least not in the way in which others expect them to). If the political construction is contingent in relation to gender and sexuality, or is not essentially linked to certain genders or sexualities, then we are all free to choose our own political standpoints, and the conversation (eventually including a negative judgment) will be established with an actual person, rather than with an ideal of what a homosexual, heterosexual, cis and/or trans* person should be.

Considering that sexuality or gender are not sufficient or necessary reasons to collectively construct a dissident political project, then we must find other ways of establishing alliances, ways that are not based on those generalizationreduction-invisibility series that appear again and again in slogans such as "Heterosexuality Kills," or in the tendency to comprise the trans* agenda in the gay and lesbian one, as if each didn't have their own specific needs, activisms, and potentialities. Why should we take sexual identities or practices as the only relevant factor when it comes to undertaking a political project? Perhaps we would be better off considering instead whether the people with whom we interact have an interest in being part of a project of dissent or political subversion with the characteristics and purposes of ours. This is about building intersectional bridges, able to include other subjects (be them within homo or trans* identities or practices or not) eager to "make noise" too, regardless of their identity or their sexual or gender practices. As Namaste has pointed out, in order to achieve real and concrete progress in people's lives, rather than looking exclusively at the specific rights of, for example, transgender people, it is essential to focus on "how these issues link with those of other marginalized populations, or with the functioning of the state in general." 22 This approach will expose the uselessness of asking about someone's gender identity or sexual orientation, and the need to focus our inquiry on their needs, intentions and political projects: do they want to "make noise" or not? In what way, by what means? With which aims? For whom?

Ever since its beginning as a movement, queer perspectives have been trying to provide options for those who want to be among the ones who "make noise". Part of the potential of this category lies precisely in the ambiguity it conveys, already evident in the fact that it can be a noun, a verb and an adjective, and that it does not refer to a static identity, but to a fluid and relational positioning. As Alfonso Ceballos Muñoz reminds us, "Queer as an adjective means that there is no immediate or simple answer to the question 'What are you?'; that there is no simple term or definite place with which or in which complex subjectivities, behaviors, desires, abilities and ambitions are situated."23 "Queer", then, would 


\begin{abstract}
${ }^{24}$ Of course, this means, among other things, breaking any idea of queerness as necessarily tied to a certain mode of sexuality or gender.
\end{abstract}

${ }^{25}$ Teresa DE LAURETIS, 1994, p. 297 be far from those sequences of reductions and (dis)identifications of sexuality and gender with political radicalism - or should be, if it wants to retain its radical potential. ${ }^{24}$

Criticisms of queer stances are numerous, and are largely focused precisely on their normalization and assimilation by a market eager to turn every transgression into a "trend." Teresa de Lauretis herself was among the first ones to notice this, as she quickly dissociated herself from the denomination she had coined. De Lauretis considered that since she "proposed it as a working hypothesis for lesbian and gay studies", Queer Theory had "very quickly become a conceptually vacuous creature of the publishing industry." 25 This leaves us with two alternatives: going ahead with the idea of queer politics, or discarding it at once and undertaking the search for other horizons. If we decide to maintain and defend this flag, we should not fall into the same problems it was meant to combat - which implies, among other things, not presupposing that a homosexual or trans* identification is necessarily and essentially radical or subversive. We are not even in a position to affirm that queerness is necessarily dissident: queerness itself as a category is not necessary and essentially anything; rather, it will be whatever we want and can do with it. Remaining alert to this flexibility of the term should be at the core of our political task, and intersectionality will undoubtedly be a fundamental tool to achieve this. If, on the contrary, we come to the conclusion that "queer" as a theoretical-political category is hopeless for a radical project, then our first task will be to think about other equally elastic and dynamic places. They will never be so completely, because our actions, like our knowledges, are situated. But it may be a good start.

\section{References}

BENNET, Jane. "Espejitos de colores" [interview]. Página/12, September 13th 2013. Available in http://www.paginal 2. com.ar/diario/suplementos/soy/1-3092-2013-09-14.html (last retrieved February 2015).

BERIIINS, Lohana. "Para nosotras, tolerancia cero". Página/12, September 7th 2012. Available in: http://www.pagina12. com.ar/diario/suplementos/soy/1-2609-2012-09-07.html (last retrieved February 2015).

BUTLER, Judith. "Is kinship always already heterosexual?". In: BUTLER, Judith. Undoing Gender. New York: Routledge, 2004. p. 102-130.

CEBALLOS MUÑOZ, Alfonso. "Teoría Rarita". In: CÓRDOBA, David, SÁEZ, Javier and VIDARTE, Francisco Javier (eds.). Teoría Queer. Second Edition. Barcelona: Egales, 2007. p. 165177. 
DE LAURETIS, Teresa. "Habit Changes". differences. A Journal of Feminist Cultural Studies, v. 6, n. 2-3, p. 296-313. 1994.

DUGGAN, Lisa. "The New Homonormativity: The Sexual Politics of Neoliberalism". In: CASTRONOVO, Russ and NELSON, Dana D. (eds.). Materialising Democracy. Durham: Duke University Press, 2002. p. 175-194.

FOUCAULT, Michel. Historia de la Sexualidad: Vol. I. Buenos Aires: Siglo XXI, 2002.

LLAMAS, Ricardo and VIDARTE, Francisco Javier. Homografías. Madrid: Espasa Calpe, 1999.

NAMASTE, Viviane. Sex Change, Social Change: Reflections on Identity, Institutions, and Imperialism. Toronto: Women's Press, 2005.

PERLONGHER, Néstor. "El sexo de las locas". In: PERLONGHER, Néstor. Prosa Plebeya. Buenos Aires: Colihue, 2008a. p. 29-34.

PERLONGHER, Néstor. "La desaparición de la homosexualidad". In: PERLONGHER, Néstor. Prosa Plebeya. Buenos Aires: Colihue, 2008b. p. 85-90.

QUEER NATION. "Queers Read This". New York Gay Pride, 1990.

RADI, Blas. "Debasements and Postfoundations: Conservative revolutions, technologies of appropriation, and the erasure of trans bodies and subjectivities in the work of Preciado". Sexualidades, n. 12, pp. 3-8, July. 2015.

RUBIN, Gayle. "Thinking sex: Notes for a radical theory of the politics of sexuality". In PARKER, Richard y AGGLETON, Peter (eds.). Culture, society and sexuality: A reader. London: UCL, 1999. p. 143-178.

SPADE, Dean. "Under the Cover of Gay Rights". N.Y.U. Review of Law and Social Change, v. 37, n. 1, p. 79-100. 2013.

STRYKER, Susan. "Transgender History, Homonormativity, and Disciplinarity". Radical History Review, n. 100, p. 145-158, winter. 2008.

[Received on 01/06/2015 and accepted on 28/04/2016]

Moira Pérez (perez.moira@gmail.com) es doctora en Filosofía (UBA); docente e investigadora. Profesora adjunta de Filosofía y de Ética en la Universidad Nacional de Lomas de Zamora/Escuela Penitenciaria Nacional); organiza talleres de Teoría Queer en la ciudad de Buenos Aires. Intereses actuales de investigación: perspectivas críticas en torno a la teoría y las políticas queer desde un enfoque interseccional; epistemologías, políticas y exclusiones de los relatos de triunfo del presente-pasado, particularmente en el contexto latinoamericanoy argentino contemporáneos; complejo industrial carcelario y construcciones de la subjetividad de sus distintas/os actoras/es. 